\title{
Analisis Peranan Motivasi Terhadap Kinerja Karyawan Pada Arengka Auto Mall Pekanbaru
}

\author{
ADI SETIAWAN \\ Sekolah Tinggi Ilmu Ekonomi Bangkinang \\ Jl. A. Rahman Saleh No. 54A Bangkinang Kota \\ E-mail : adisetiawan@gmail.com
}

\begin{abstract}
This study aims to determine the effect of motivation on employee performance at Arengka Auto Mall Pekanbaru. Performance is the result of work (output) both quality and quantity achieved by human resources in a period of time in carrying out their work duties in accordance with the responsibilities given to them. The analysis in this study uses a simple linear analysis with 51 respondents. Sampling uses a census technique that is the entire population is sampled. Hypothesis testing using the $t$ test. based on the results of this study concluded that motivation has a significant effect on employee performance at Arengka Auto Mall Pekanbaru. There is a strong positive relationship between motivation and performance and the contribution of the independent variable to the dependent variable of $68.06 \%$.
\end{abstract}

Keywords: Motivation, Performance

Era globalisasi yang terjadi saat ini mempunyai dampak bagi perkembangan usaha. Dampak yang sangat jelas terlihat adalah adanya persaingan dalam dunia usaha. Persaingan tersebut semakin ketat sehingga membuat perusahaan terus berlomba-lomba melakukan inovasi untuk memenangkan persaingan. Perusahaan akan berusaha untuk mencapai tujuan dengan efektif dan efisien. Hal itu dilakukan agar perusahaan mampu mempunyai daya saing atau unggul dari pesaingnya

Keunggulan suatu perusahaan bisa dicapai melalui beberapa faktor. Salah satu faktor tersebut adalah kemampuan internal perusahaan melalui sumber daya yang dimiliki perusahaan. Setiap perusahaan harus mampu mengelola sumber daya yang ada untuk dapat bekerja menjalankan aktifitas perusahaan agar tujuan perusahaan tercapai, dengan cara memotivasi karyawan sehingga dapat meningkatkan kinerja karyawan.

Motivasi merupakan dorongan terhadap serangakaian proses prilaku karyawan pada pencapaian tujuan perusahaan dan mengandung elemen yang meliputi unsur membangkitkan, mengarahkan, menjaga, menunjukkan intensitas, bersifat terus menerus dan adanya tujuan. Oleh karena itu pemberian motivasi pada karyawan harus dijadikan sebagai skala prioritas dalam mengembangkan kinerja karyawan. Salah satu indikator dari motivasi adalah kebutuhan, karyawan mempunyai kebutuhan tertentu dan akan berupaya untuk memenuhi kebutuhan tersebut dengan melaksanakan serangkaian aktivitas atau kegiatan.

Arengka Auto Mall adalah salah satu perusahaan yang bergerak dibidang bisnis penjualan mobil bekas dan baru yang berlokasi di jalan Arengka I pasar pagi Pekanbaru, dalam menjalankan usaha Arengka Auto Mal banyak menghadapi pesaing, untuk itu perlu memiliki karyawan yang handal serta perlunya pengelolaan sumber daya manusia yang optimal melalui pemberian motivasi Intrinsik (dorongan dari dalam diri karyawan itu sendiri) maupun motivasi Ekstrinsik (dorongan dari perusahaan) dengan memenuhi kebutuhan karyawan seperti gaji yang memuaskan, adanya reward, kondisi kerja yang mendukung. Tidak semua kebutuhan karyawan dapat dipenuhi oleh perusahaan, hal ini akan berdampak kepada turunnya kinerja karyawan.

Hal yang perlu diperhatikan untuk memaksimalkan kinerja secara internal, kita perlu mengetahui motivasi kerja karyawan sehingga produktivitas dapat ditingkatkan. Pencapaian kinerja harus sesuai dengan tujuan organisasi. Kemajuan dan keberhasilan organisasi sangat bergantung pada kinerja individu 
dalam hal ini karyawan, dimana karyawan tersebut mampu bekerja keras, proaktif, loyal serta disiplin tinggi dan bertanggung jawab terhadap tugas dan pekerjaan yang pada akhirnya dapat mencapai kinerja yang optimal sehingga berdampak positif pada kinerja organisasi.

Pemberian motivasi yang tepat akan memacu daya penggerak untuk menciptakan kegairahan kerja seseorang agar mereka mau bekerja sama dengan efektif dan terintegrasi dengan segala daya upayanya untuk mencapai kepuasan, selain itu motivasi dapat menjadi penyebab maupun mendukung prilaku seseorang sehingga orang tersebut berkeinginan untuk berkerja keras dan antusias untuk mencapai hasil yang optimal.

Manajemen sumber daya manusia merupakan bagian dari manajemen umum yang memfokuskan diri pada unsur sumberdaya manusia dan juga suatu gerakan pengakuan terhadap pentingnya unsur manusia sebagai sumber daya manusia yang cukup potensial yang perlu dikembangkan sehingga mampu memberikan kontribusi yang maksimal bagi organisasi maupun pengembangan diri sendiri.

Menurut Rivai (2011:1) mengatakan bahwa manajemen sumber daya manusia merupakan salah satu bidang dari manajemen umum yang meliputi perencanaan, pengorganisasian, pelaksanaan dan pengendalian. Sedangkan menurut sondang (2016:41) menyatakan bahwa manajemen sumber daya manusia adalah langkah-langkah tertentu yang diambil oleh manajemen guna lebih menjamin bahwa bahwa organisasi tersedia tenaga kerja yang tepat untuk menduduki berbagai kedudukan, jabatan, dan pekerjaan yang tepat pada waktu yang tepat kesemuanya dalam rangka pencapaian tujuan dan berbagai sasaran yang telah dan akan ditetapkan.

Adapun fungsi manajemen sumber daya manusia menurut Hasibuan (2013:12) secara umum adalah sebagai berikut : perencanaan, pengorganisasian, pengarahan, pengendalian, pengadaan, pengembangan, kompensasi pengintegrasian, pemeliharaan, kedisiplinan, pemberhentian.

Adapun fungsi-fungsi manajemen

SDM (Malayu S.P Hasibuan, 2013:21) seperti halnya fungsi manajemen umum, yaitu: Perencanaan (planning), Merencanakan tenaga kerja secara efektif serta efisien agar sesuai dengan kebutuhan perusahaan dalam rangka membantu terwujudnya tujuan. Pengorganisasian (organization), Kegiatan untuk mengorganisasi semua karyawan dengan menetapkan pembagian kerja, hubungan kerja, delegasi wewenang, integrasi dan koordinasi dalam bagan organisasi. Pengarahan (directing), Kegiatan mengarahkan semua karyawan agar mau bekerjasama dan bekerja efektif dan efisien dalam membantu terwujudnya tujuan perusahaan. Pengendalian (controlling). Kegiatan mengendalikan semua karyawan agar mentaati peraturan-peraturan perusahaan dan bekerja sesuai rencana. Apabila terdapat penyimpangan atau kesalahan maka diadakan tindakan perbaikan dan penyempurnaan rencana. Pengadaan (procurement), Proses penarikan, seleksi, penempatan, orientasi dan induksi untuk mendapatkan karyawan yang sesuai dengan kebutuhan perusahaan. Pengembangan (development), Proses peningkatan keterampilan teknik, teoritis, konseptual, dan moral karyawan melalui pendidikan dan pelatihan. Pendidikan dan pelatihan yang diberikan harus sesuai dengan kebutuhan pekerjaan masa kini maupun masa depan. Kompensasi (compensation), Pemberian balas jasa langsung (direct) dan tidak langsung (inderect), uang atau barang kepada karyawan sebagai imbalan jasa yang diberikan kepada perusahaan. Pengintegrasian (integration), Kegiatan untuk mempersatukan kepentingan perusahaan dan kebutuhan karyawan, agar tercipta kerjasama yang serasi dan saling menguntungkan. Perusahaan akan memperoleh laba sedangkan karyawan 
dapat memenuhi kebutuhan dari hasil pekerjaannya. Pemeliharaan (maintenance), Kegiatan untuk memelihara atau meningkatkan kondisi fisik, mental dan loyalitas karyawan agar mereka tetap mau bekerja sama sampai prnsiun. Pemberhentian (separation), Putusnya hubungan karyawan seseorang dari suatu perusahaan. Pemberhetian ini disebabkan oleh keinginan karyawan, keinginan perusahaan, kontrak kerja berakhir, pensiun dan sebab-sebab lainnya

Dari beberapa penjelasan diatas dapat ditarik kesimpulan bahwa Manajemen Sumber Daya Manusia merupakan suatu proses yang menggabungkan fungsi-fungsi manajemen (perencanaan, pengorganisasian, pelaksanaan, dan pengawasan) dengan fungsi-fungsi sumber daya manusia (penarikan, seleksi, penggembangan, kompensasi, evaluasi, promosi) untuk mencapai tujuan individu dan masyarakat.

Kelangsungan hidup sebuah perusahaan adalah bagaimana kinerja yang dimiliki oleh para karyawannya dalam beraktifitas untuk mencapai tujuan dan prioritas perusahaan tersebut. Kinerja dapat didefinisikan sebagai perilaku atau apa yang dilakukan oleh seorang karyawan, bukannya apa yang diproduksinya atau apa yang dihasilkan dari kerja mereka (Suwarto, 2014:23). Dengan demikian, maka definisi kinerja tidak mencakup hasil dari perilaku pegawai, tetapi perilaku itu sendiri (Suwarto, 2014:23).

Definisi kinerja juga dapat digambarkan mempunyai hubungan multiplikatif dimana kinerja merupakan gabungan dari pengetahuan deklaratif, pengetahuan prosedural dan motivasi. Pengetahuan deklaratif adalah informasi tentang fakta-fakta dan hal-hal termasuk informasi mengenai persyaratan tugas yang diberikan, label, prinsip, dan tujuan. Pengetahuan prosedural adalah kombinasi antara apa yang harus dilakukan dan bagaimana cara melakukannya, pengetahuan ini mencakup keterampilan- keterampilan yang bersifat kognitif, motor, dan interpersonal.

Menurut Rizal (2016:12) adalah sebagai hasil kerja secara kualitas dan kuantitas yang dapat dicapai oleh seorang karyawan dalam melaksanakan tugas sesuai dengan tanggung jawab yang diberikan kepadanya. Agar kinerja karyawan selalu konsisten maka organisasi harus selalu memperhatikan motivasi kerjanya indikatornya adalah kualitas, kuantitas, lama jam kerja, menyelesaikan pekerjaan sesuai mekanisme, bekerja keras, bekerja secara tim, saling mengisi dan mendukung, absensi selalu baik, tugas sesuai kemampuan dan sesuai waktu dan jumlah pekerjaan.

Kinerja memberikan arti yangbesar terhadap perusahaan, karena kinerja merupakan sebuah kontribusi yang sangat menentukan hasil dari sebuah sasaran atau tujuan dari perusahaan. Prawirosentono (2015:193) menegaskan bahwa terdapat hubungan yang erat antara kinerja perorangan (individual performance) dengan kinerja lembaga (institutional performance) atau kinerja perusahaan (corporate performance) Dengan kata lain apabila karyawan memiliki kinerja yang baik, maka kemungkinan besar kinerja perusahaan juga baik.

Menurut (Suwarto, 2014:23) ada 2 ciri perilaku yang bisa dilabelkan sebagai kinerja yaitu : Kinerja yang evaluatif. Ini berarti bahwa kinerja semacam itu bisa dinilai negatif, netral, atau posisitf bagi efektivitas perorangan dan organisasi. Dengan kata lain, nilai perilaku ini bisa bervariasi berdasarkan apakah mereka memberikan sumbangan untuk pelaksanaan maksud untuk tujuan perorangan, unit dan organisasi. Kinerja yang multidimensional. Ini berarti bahwa terdapat banyak jenis perilaku berbedabeda yang mempunyai kapasitas untuk memajukan (atau menghambat) tujuan organisasi.

Dari uraian di atas penulis menyimpulkan bahwa kinerja sumber 
daya manusia adalah prestasi kerja atau hasil kerja (output) baik kualitas maupun kuantitas yang dicapai sumber daya manusia persatuan periode waktu dalam melaksanakan tugas kerjanya sesuai dengan tanggung jawab yang diberikan kepadanya. Kinerja merupakan hal penting yang harus dicapai oleh setiap organisasi, karena kinerja merupakan cerminan dari kemampuan organisasi dalam mengelola dan mengalokasikan sumber dayanya.

Hipotesis pada penelitian ini adalah: "Diduga motivasi berpengaruh terhadap Kinerja Karyawan pada Arengka Auto Mall Pekanbaru.

\section{METODE}

Penelitian dilakukan pada Arengka Auto Mall Pekanbaru dengan waktu penelitian selama 2 (Dua) bulan mulai dari bulan Februari sampai dengan bulan April 2019. Jenis data yang digunakan dalam penelitian ini adalah data Kualitatif dan data Kuantitatif. Populasi dalam penelitian ini adalah Karyawan Arengka Auto Mall Pekanbaru yang berjumlah 51 orang.

Sampel menurut Sugiyono (2017:81) merupakan bagian dari populasi yang ingin diteliti oleh peneliti. Teknik pengambilan sampel menggunakan teknik sensus yaitu seluruh populasi dijadikan sampel. Jadi jumlah sampel pada penelitian ini berjumlah 51 sampel.

Untuk menganalisa data dan menjawab permasalahan dalam penelitian ini maka penulis menggunakan model persamaan regresi linear sederhana, dengan persamaan sebagai berikut (Suryana,2010).

$\mathrm{Y}=\alpha+\mathrm{bX}+\varepsilon$

Dimana:

$\begin{array}{lll}\mathrm{Y} & = & \text { Kinerja } \\ \mathrm{X} & = & \text { Motivasi } \\ \alpha & = & \text { konstanta (nilai Y apabila } \mathrm{X}= \\ 0) & & \text { koefisien regresi (nilai } \\ \mathrm{b} & = & \begin{array}{l}\text { peningkatan ataupun } \\ \text { penurunan) }\end{array} \\ & & \text { Error Term }\end{array}$

Jurnal Daya Saing (Vol. 5, No. 3 Okober 2019)

\section{HASIL}

Pengujian ini bertujuan untuk melihat apakah data yang digunakan mengikuti pola distribusi normal atau tidak. Karena model yang baik, data harus mengikuti pola distribusi normal. Hasil pada pengujian Normalita dapat dilihat pada gambar berikut.

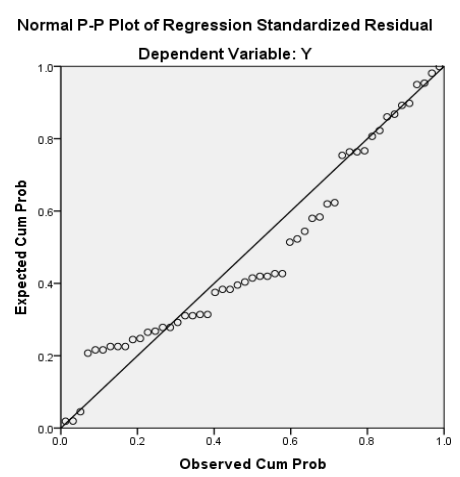

Berdasarkan Gambar diatas dapat dilihat bahwa data menyebar disepanjang garis diagonal, dengan demikian berarti data atau nilai residual sudah mengikuti disbtribusi normal.

\section{Analisis Regresi Linier}

Berdasarkan hasil pengolahan data didapat nilai konstanta dan koefisien regresi sehingga dapat dibentuk persamaan regresi linier sederhana sebagai berikut: $\mathrm{Y}=0,457+0,811(\mathrm{X})$

a. 0,457 yang berarti jika motivasi (X) bernilai 0 , maka kinerja (Y) akan bernilai 0,457 satuan.

b. 0,811 yang berarti jika motivasi (X) meningkat sebesar satu satuan maka kinerja (Y) akan meningkat sebesar 0,811 satuan.

Perhitungan statistik pada analisis ini dapat dilihat pada tabel berikut:

Tabel 1. : Hasil Analisis Regresi Linier Sederhana

\section{Coefficients $^{\mathbf{a}}$}

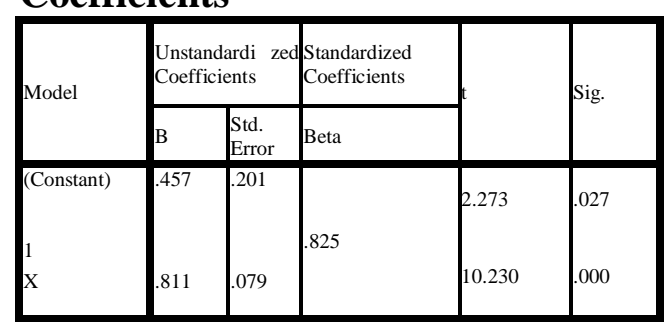

a. Dependent Variable: Y

p.ISSN: $2407-800 \mathrm{X}$

e.ISSN: $2541-4356$ 


\section{Hasil Uji t}

Dari hasil perhitungan tabel 1 diatas, diperoleh nilai $\mathrm{t}$ hitung untuk variabel motivasi (X) sebesar 10,230 dengan nilai signifikan sebesar $0,000<0,05$. Berdasarkan hasil signifikan yang didapat, ternyata signifikansi variabel Motivasi lebih kecil dari $0,05(0,000<0,05)$, artinya terdapat pengaruh yang signifikan dari variabel motivasi terhadap kinerja karyawan pada Arengka Auto Mall Pekanbaru.

\section{Koefisien Korelsi (r)}

Analisis koefisien korelsi (r) digunakan untuk menerangkan kekuatan dan arah hubungan antara variable independen dengan variable dependen. Penulis mengunakan analisis korelasi sederhana untuk mengatur kekuatan asosiasi (hubungan) antara variabel independen dan variabel dependen (Sugiyono, 2017).

Berdasarkan hasil analisis Koefisien Korelasi, didapatkan hasil bahwa motivasi terhadap kinerja berpengaruh sebesar $68,06 \%$, sedangkan sisanya $31,56 \%$ dipengaruhi oleh variabel lain yang tidak diteliti dalam penelitian ini.

\section{PEMBAHASAN}

Berdasarkan analisis deskriptif pada variabel motivasi, tanggapan dari para responden berada dalam kategori setuju. Kebutuhan rasa aman dan kebutuhan fisiologi termasuk ke dalam kategori setuju dan kebutuhan sosial, kebutuhan penghargaan dan kebutuhan aktualisasi diri termasuk dalam kategori sangat setuju. Berdasarkan analisis deskriptif pada variabel kinerja, tanggapan responden berada dalam kategori sangat setuju. Dimensi kuantitas dan kualitas kerja masuk ke dalam kategori sangat setuju, dimensi keandalan dan attitude masuk ke dalam kategori setuju.

\section{SIMPULAN}

Berdasarkan hasil penelitian penulis menyimpulkan bahwa motivasi berpengaruh positif dan signifikan terhadap kinerja karyawan pada Arengka Auto Mall
Pekanbaru.

\section{DAFTAR RUJUKAN}

Vietzal, Rivai. 2011. Manajemen sumber daya manusia untuk Perusahaan. Jakarta: PT. Raja Grafindo Persada

Sondang P. Siagian. 2016. Sistem Informasi Manajemen, Bumi Aksara. Jakarta.

Hasibuan, Malayu. 2013. Manajemen Sumber Daya Manusia. Jakarta: Bumi Aksara.

Suwarto. 2014. Pengaruh Stres Kerja dan Motivasi Kerja Terhadap Kepuasan Kerja Karyawan PT. Sorini Agro Asia Orindo Tbk, Cabang Lampung. Derivatif Jurnal Manajemen. Volume 8, No. 2.

Rizal Rachman. 2016. Pengaruh disiplin kerja dan lingkungan kerja terhadap motivasi dampaknua pada kinerja karyawan di PT. Asia Penta Garment. STMIK Nusa Mandiri Jakarta. Jurnal ISBN: 978602-72850-3-3 SNIPTEK.

Prawirosentono, Suyadi. 2015. Manajemen Sumber Daya Manusia : Kebijakan Kinerja Karyawan. Penerbit BPFE Yogyakarta

Sugiyono. 2017. Metode Penelitian Kuantitatif Kualitatif dan $R \& D$. Bandung: Alfabeta.

Suryana, 2010. Metode Penelitian Model Praktis Penelitian Kuantitatif dan Kualitatif, Bandung : UPI 